Iranian Journal of Breast

Diseases. 2022; 14(4):31-44.

\section{Original Article \\ Correlations of Diabetes and the Risk Factors with the Survival of Breast Cancer Patients}

\author{
Sharifi Nasab $\mathbf{M}^{1,2}$, Yazdimoghaddam $\mathbf{H}^{3^{*}}$, Mohaddes $\mathrm{T}^{4}$, Rakhshani $\mathbf{M H}^{5}$ \\ ${ }^{1}$ Faculty of Nursing and Midwifery, Sabzevar University of Medical Sciences, \\ Sabzevar, Iran \\ ${ }^{2}$ Department of Nursing, Ghaem Hospital, Mashhad University of Medical Sciences, \\ Mashhad, Iran \\ ${ }^{3}$ Department of Operating Room, Iranian Research Center on Healthy Aging, Faculty of \\ Paramedics, Sabzevar University of Medical Sciences, Sabzevar, Iran \\ ${ }^{4}$ Department of Hematology \& Medical Oncology, Ghaem Hospital, Faculty of \\ Medicine, Mashhad University of Medical Sciences, Mashhad, Iran \\ ${ }^{5}$ Department of Biostatistics and epidemiology, Iranian Research Center on Health \\ Aging, School of Public Health, Sabzevar University of Medical Sciences, Sabzevar, \\ Iran
}

\author{
Receive: $10 / 9 / 2021$ \\ Accepted: 22/12/2021 \\ "Corresponding Author: \\ ha_yazdimoghaddam@yahoo.com \\ Ethics Approval: \\ IR.MEDSAB.REC.1397.020
}

\begin{abstract}
Introduction: Diabetes is associated with an increased risk of cancer. Because of the metastatic nature of cancer, the survival of women with breast cancer is decreasing despite receiving various treatments such as chemotherapy, radiotherapy, etc. The aim of this study was to investigate the relationship between diabetes and the risk factors related to the survival of breast cancer patients.
\end{abstract}

Methods: This was a descriptive-analytical study. Patients were selected via systematic random sampling and then divided into diabetic and nondiabetic groups. Then the 5-year survival rate of patients was were compared.

Results: The mean and median for survival were 9.95 and 13.00 years. The risk of death in breast cancer patients positive for estrogen receptor was significantly reduced compared with patients negative for estrogen receptor (HR, 0.314; 95\% CI, 0.109-0.907; $\mathrm{P}=0.03$ ).

Conclusion: The results of the study indicate that the survival of breast cancer patients in diabetics is not significantly different from non-diabeticsUse of metformin and estrogen receptor positivity is associated with higher 5-year survival rates in women with breast cancer. Therefore, cancer screening programs in high-risk groups, especially in diabetic patients, and hyperglycemic control may affect survival time.

Keywords: Diabetes, Breast Neoplasms, Survival Time, Metformin 


\section{Introduction}

Cancer is a major public health threat across the world, especially in developing countries. The incidence rate of cancer is increasing due to the prevalence of its risk factors, such as smoking, obesity, and physical inactivity (1). Notably, breast cancer is a more prevalent malignancy among Iranian women and the fourth leading cause of cancer death in the world (2). The number of new cancer cases has remarkably increased and cancer death is predicted to reach over 11.4 million in 2030 across the world, manifesting cancer to be a major cause of death. Based on the scientific reports, up to $40 \%$ of cancers could be prevented if the risk factors were decreased (3). The correlation between type 2 diabetes and some types of cancer has been identified, while this diagnostic complexity is remarkably increasing. However, cancer, especially breast cancer, is affected by some risk factors, including diabetes, insulin resistance, obesity, smoking habits, socioeconomic status, age, gender, ethnicity, and hormone receptors such as estrogen and progesterone.

The global prevalence of diabetes as a risk factor for cancer has a message to take the disease more seriously (4). Research has investigated the mechanisms through which diabetes and cancer are associated. Because of the metastatic nature of the disease, the survival of women with breast cancer is decreasing despite receiving various treatments such as chemotherapy, radiotherapy, etc.; on the other hand, if these patients also have diabetes, the complications related to diabetes can cause problems, which are likely to affect the survival of patients. Therefore, control of risk factors, especially diabetes, and careful control of hyperglycemia in these patients will be very important in increasing their survival. The aim of this study was to investigate the relationship between diabetes and risk factors with the survival of patients with breast cancer in cancer treatment centers affiliated with Mashhad University of Medical Sciences.

\section{Materials and Methods}

This descriptive-analytical study used data for patients diagnosed with breast cancer who were receiving treatment at the cancer treatment centers. The study population included the women patients diagnosed with breast cancer referred to the chemotherapy and hematology-oncology departments of Imam Reza and Ghaem hospitals, Mashhad, Iran. These patients were followed up to evaluate 5-year survival since diagnosis. The breast cancer diagnosis was confirmed based on the criteria of the International Classification of Diseases (ICD), the American Commission on Cancer, and pathology reports. Diabetes had been diagnosed using fasting blood sugar (FBS) and $\mathrm{HbA} 1 \mathrm{c}$ tests.

\section{Results}

The prevalence of diabetes in breast cancer patients was $12.7 \%$, and the mean duration of having diabetes was $8.27 \pm 4.71$ years. The mean survival rates of nondiabetic and diabetic patients with breast cancer were 10.021 and 7.420 years, respectively. To investigate the impacts of diabetes on the survival rate of breast cancer patients in the presence of effective factors, such as age (at menarche, menopause, and the first full-term pregnancy), smoking habits, history of OCP use, BMI, estrogen and progesterone receptors, HER2 and HER2 receptor subtype status, and molecular subtype of cancer (luminal A vs luminal B), the data were fitted in the Cox regression model. However, findings indicated no significant differences between survival time of diabetic and nondiabetic patients (HR, 0.758; 95\% CI, $0.431-1.334 ; \mathrm{P}=0.34$ ). Based on the abovementioned risk factors, mortality risk significantly decreased in patients with estrogen receptor-positive breast cancer compared with those with estrogen receptornegative tumors $(\mathrm{P}=0.03)$. With regard to diabetes-controlling drugs, the Cox regression model indicated that mortality risk was significantly decreased in patients receiving metformin ( $\mathrm{HR}, 0.5 ; 95 \% \mathrm{CI}$, 0.226-0.950; $\mathrm{P}=0.04)$. However, insulin injection was not associated with the survival rate of breast cancer patients. 


\section{Discussion}

In the current research, no significant difference was observed between diabetic and nondiabetic groups in terms of survival rate, which is consistent with VillarrealGarza et al. (5). Therefore, it seems that diabetes does not affect the survival rate independently. In another study, De Bruijn et al. considered diabetes to be a risk factor for breast cancer and cancer death (6). In a similar study, Currie et al. reported an increased mortality rate associated with cancer, especially breast cancer, in diabetic patients compared with nondiabetic ones (7). Furthermore, the results obtained by Erickson et al. showed a significant reduction in the overall survival rate of the survivors of primary breast cancer with chronic hyperglycemia (8). This discrepancy between our findings and the aforementioned studies might be due to metformin use in diabetic patients with breast cancer, which was observed to increase the survival rate of our subjects. In summary, further investigation is recommended to confirm our findings.

\section{References}

1. Torre LA, Bray F, Siegel RL, Ferlay J, LortetTieulent J, Jemal A. Global cancer statistics, 2012. CA Cancer J Clin 2015;65(2):87-108.

2. Akbari ME, Sayad S, Sayad S, Khayamzadeh M, Shojaee L, Shormeji Z, et al. Breast Cancer Status in Iran: Statistical Analysis of 3010 Cases between 1998 and 2014. Int J Breast Cancer 2017; 2017:2481021.

3. Bray F, Jemal A, Grey N, Ferlay J, Forman D. Global cancer transitions according to the Human Development Index (2008-2030): a population-based study. Lancet Oncol 2012; 13(8):790-801.

4. Pandey A, Forte V, Abdallah M, Alickaj A, Mahmud S, Asad S, et al. Diabetes mellitus and the risk of cancer. Minerva endocrinologica 2011; 36(3):187-209.

5. Villarreal-Garza C, Shaw-Dulin R, LaraMedina F, Bacon L, Rivera D, Urzua L, et al.

\section{Conclusion}

The high prevalence of breast cancer is an important public health issue. According to the study results, diabetic patients are at risk of developing types of cancer, especially breast cancer, due to drug treatments and the presence of risk factors; therefore, screening is important. Given the increased survival in metformin-treated patients, the importance of treating hyperglycemia in diabetic patients with breast cancer is important. Therefore, early screening of diabetic women by physicians, for faster diagnosis of breast cancer at early stages and timely treatment and prevention of metastasis, can improve their survival.

Given the increased risk of death in patients with metastasis, identifying risk factors and early diagnosis could be effective in increasing the survival of patients with breast cancer.

\section{Acknowledgment}

This article is extracted from the Master's thesis in nursing approved by Sabzevar University of Medical Sciences with code 97081. Hereby, we extend our gratitude to the authorities of the hospitals affiliated to Mashhad University of Medical Sciences for assisting us in this research project.

Impact of diabetes and hyperglycemia on survival in advanced breast cancer patients. Exp Diabetes Res. 2012; 2012.

6. De Bruijn K, Arends L, Hansen B, Leeflang S, Ruiter R, Van Eijck C. Systematic review and meta- analysis of the association between diabetes mellitus and incidence and mortality in breast and colorectal cancer. Br J Surg. 2013; 100(11):1421-9.

7. Currie CJ, Poole CD, Jenkins-Jones S, Gale EA, Johnson JA, Morgan CL. Mortality after incident cancer in people with and without type 2 diabetes: impact of metformin on survival. Diabetes care. 2012; 35(2):299-304.

8. Erickson K, Patterson RE, Flatt SW, Natarajan L, Parker BA, Heath DD, et al. clinically defined type 2 diabetes mellitus and prognosis in early-stage breast cancer. J Clin Oncol. 2011; 29(1):54-60. 
مقاله يُروهشى

بررسى رابطه بيمارى ديابت و عوامل خطر مرتبط با بقاى بيماران مبـتلا بــــ

سرطان بستان

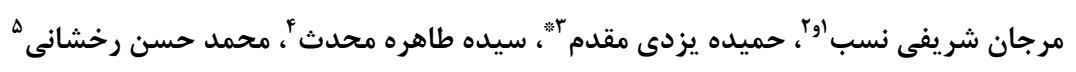

'دانشكده يرستارى و مامايى، دانشكاه علوم يزشكى سبزوار، سبزوار، ايران

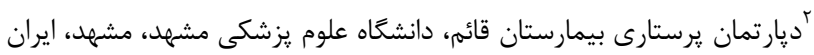

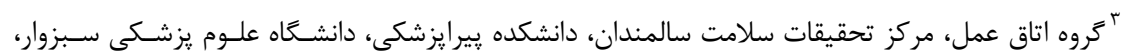

سبزوار، ايران

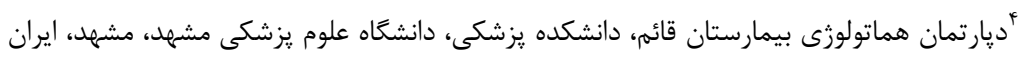

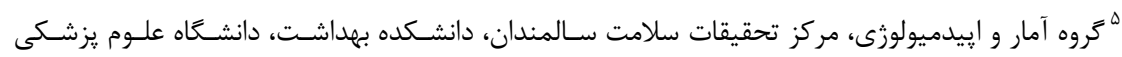

سبزوار، سبزوار، ايران
فصلنامه بيمارى هاى يستان ايران

$|\varepsilon \cdot . !| \varepsilon(\varepsilon): r \mid-\varepsilon \varepsilon$ ous?

مقدمه: ديابت با افزايش خطر ابتلا به سرطان يستان ارتباط دارد. زمان بقاى زنان مبتلا به سرطان

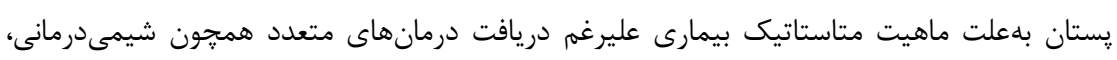

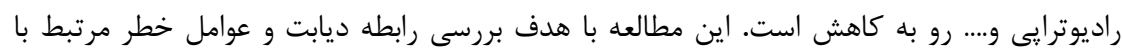

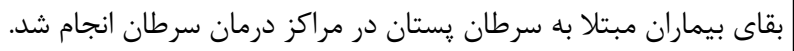
روش بررسى: اين مطالعه به صورت توصيفى - تحليلى انجام گرفت. بيماران با روش نمونهيرى

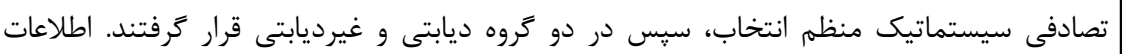

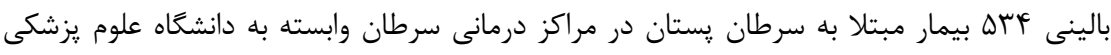

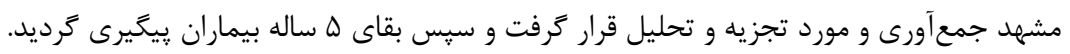

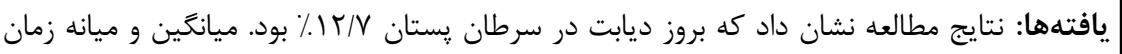

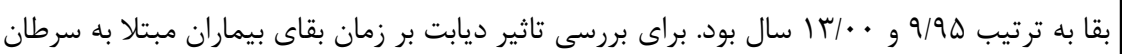

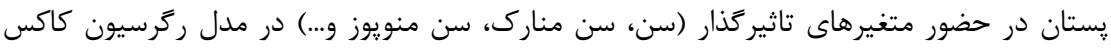

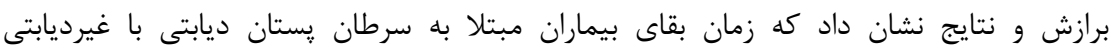

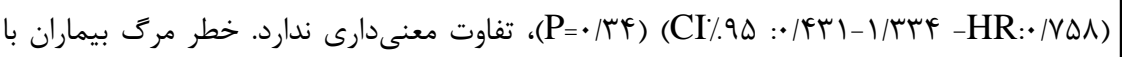

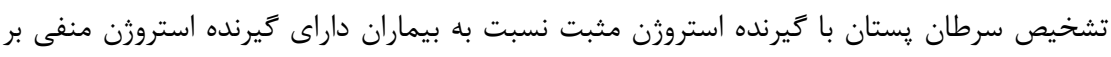

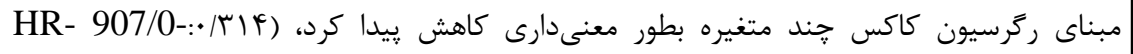
(109/0: 95\% CI

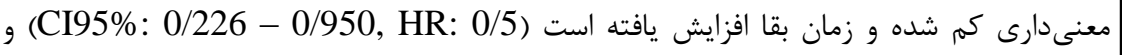
. $(\mathrm{P}=\cdot / \cdot \mathrm{F})$ نتيجهَيرى: نتايج مطالعه حاضر نشان داد كه زمان بقاى بيماران مبتلا به سرطان پِّتان در افراد

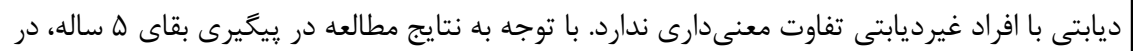

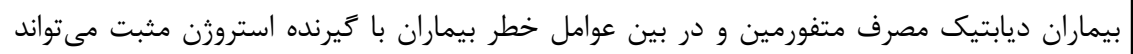

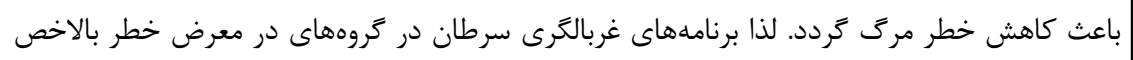

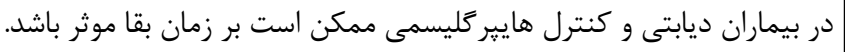
| وازههاى كليدى: ديابت، سرطان يستان، زمان بقا، متفورمين

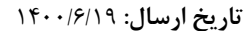

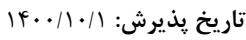

"ن نويسنده مسئول: ha_yazdimoghaddam@yahoo.com 
توسعه يافته را مبتلا مى كند (• (1) ارتباط بين ديابت نوع r و برخى از انواع سرطان در حال شناسايى است، بلهورى كه بسيارى از عوامل خطر شامل سن، جنس،

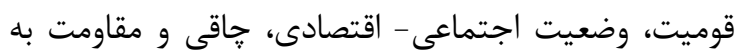
انسولين، فعاليت بدنى و سيكار كشيدن و ابتلا به ديابت،

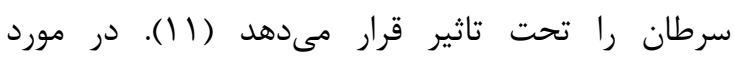
مكانيسمهاى ارتباط ديابت و سرطان فرضيههايى مطرح شده كه نياز به بررسى بيشتر دارد (YI). انواع مختلف

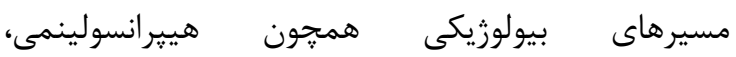
هيير كليسمى و نيز وضعيت ضدالتهاب دائمى بهعنوان عوامل خطر ابتلا به سرطان در ديابت مطرح شدهاند (ب ا ). مكانيسمهاى يِيشبينى شده براى افزايش خطر سرطان در در

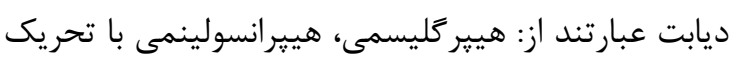

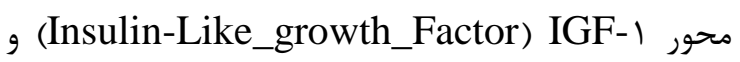
جاقى، كه به عنوان يك فرضيه مشترك براى سرطان و ديابت مطرح شدند (f) (1). ارتباط بين ديابت و سرطان

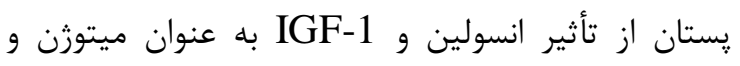
همجنين تأثير آن بر سطح هورمون استروزن حمايت آنسيت

مى كند (1) (1).

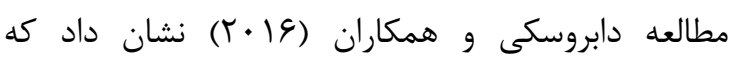
شايعترين بدخيمى در زنان ديابتى، سرطان يستان بوده

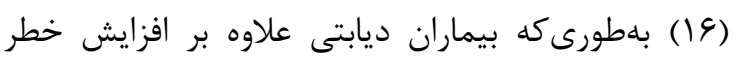

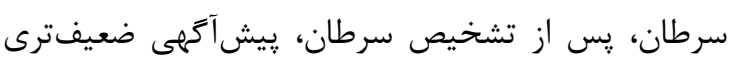

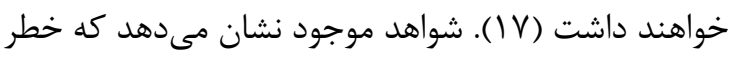
مرى ناشى از سرطان يستان، در زنان ديابتى افزايش مى يابد. با اين وجود هنوز مشخص نيست كه آيا ديابت بايد يك عامل خطر مستقل براى اين نئويلاسمها باشد يا بإيا

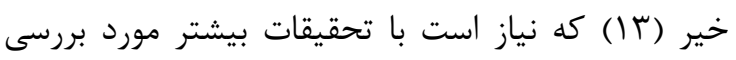

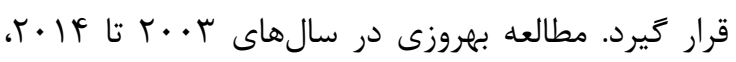

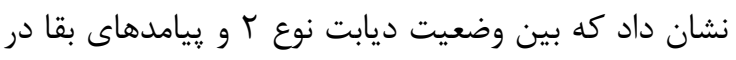

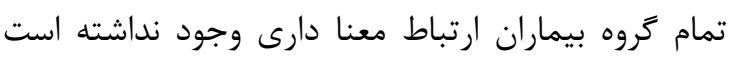

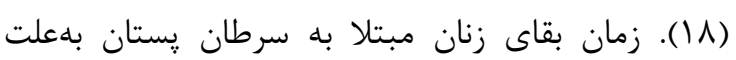

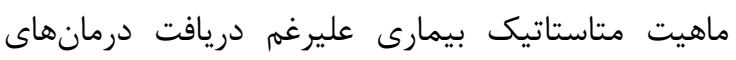

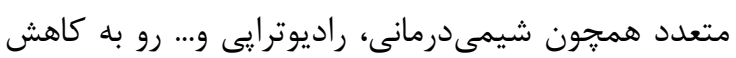
سرطان يكى از بزركترين تهديدهاى سلامت عمومى در جهان به خصوص در كشورهاى در حال توسعه است (1).

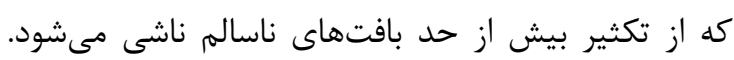

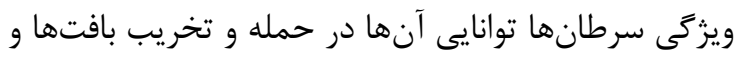

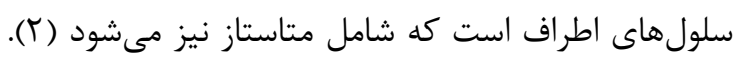
وقوع سرطان بهدليل افزايش شيوع فاكتورهاى خطرزا ماند سيگار، جاقى، بى حركتى در حال افزايش است (بان).

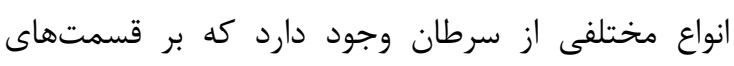

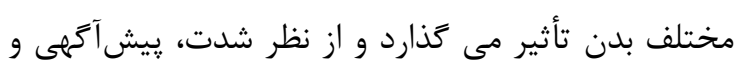

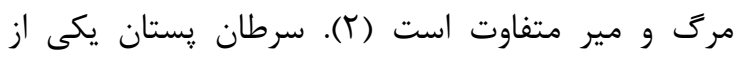

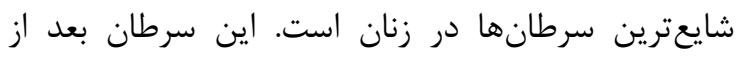

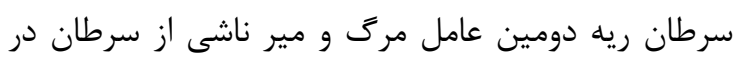

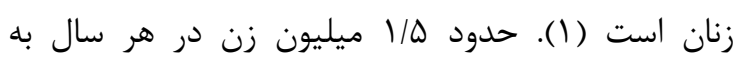
سرطان رِتان مبتلا مىشوند (l) (1).

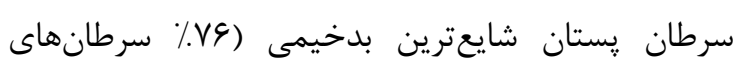
شايع) (ه) و عامل اصلى مرك ناشى از سرطان در ميان

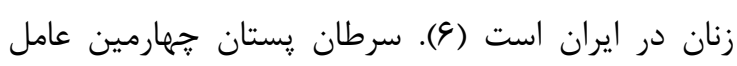

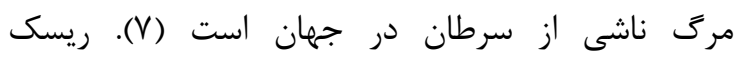

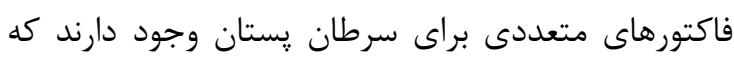

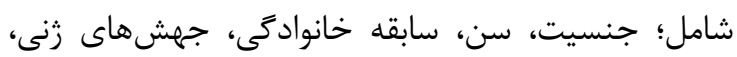

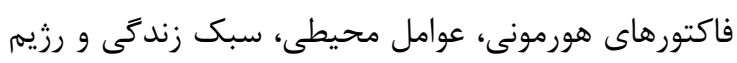
غذايى است (^). ميانگَين بقاى پينج ساله زنان ايرانى مبتلا

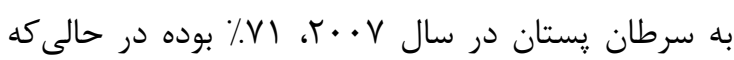

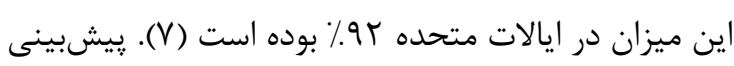

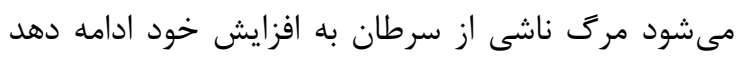

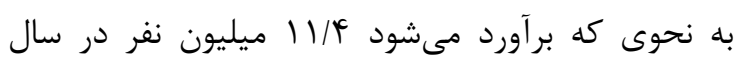

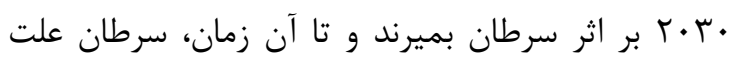

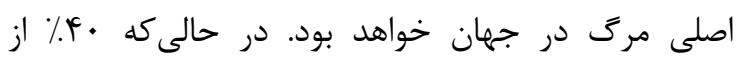
سرطانها را مىتوان با تعديل عوامل خطر بِيشگيرى نمود

نتايج مطالعه مرورى اكتوند (·r (Y)، ارتباط بين ديابت و

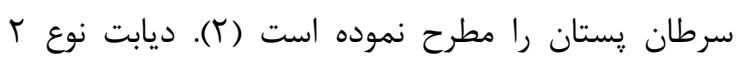

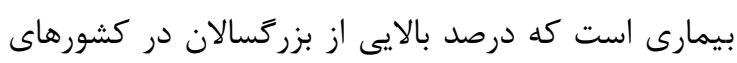


از طريق شمارش دستى و سيستمى تعداد يروندههاى

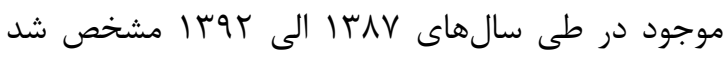
تا عدد k براى شروع نمونهگيرى بهدست آيد. در اين روش تعداد نمونه مورد نياز (n) از كل جامعه آمارى (N)

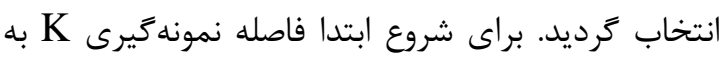
صورت (تعداد اعضاى نمونه / تعداد اعضاى جامعه مورد مطالعه = K )، محاسبه گرديد كه عدد ץ بهدست آمد. سيس بين عدد ا تا k يك عدد به طور تصادفى انتخاب كرديم و بعد افراد بعدى را با فاصله k از عدد مذكور انتخاب نموديم. در اين روش حتما تهيه ليست از جامعه مورد مطالعه قبل از همه لازم است، كه طى فرايند فوق انجام گرديد. با توجه به حجم نمونه، يس از تقسيم حجم بين ينج سال، حجم نمونه براى سرطان يستان در هر سال بهدست آمد. بدين شرح كه يزوهشخر با مراجعه به بخشهاى مورد نظر در هر سال، به روش نمونه سيستماتيك بر حسب عدد K بهدست آمده، يك عدد به صورت تصادفى از بين عدد ا تا k يروندههاى مربوط به نمونههاى يزوهش انتخاب كه بهعنوان يرونده اولين بيمار در نظر كرفته مىشد و سيس يروندههاى بيماران ديخر بر اساس عدد k شمارش، انتخاب و بهطور دقيق متغيرهاى مربوط به نمونههاى يزوهش استخراج و اطلاعات مورد نياز آنها مورد بررسى قرار گرفتند. به طور كلى دادهاى بالينى F ب هآ بيمار واجد شرايط از سوابق يزشكى به دست آمد. سيس بر اساس تشخيص ديابت، بيماران در دو گروه ديابتى و غيرديابتى قرار كَفتند. در بررسى بيمارانى كه بر اساس اطلاعات يرونده در حال درمان و مراجعه به مراكز درمانى بودند طبق هماهنگى در مواجهه حضورى در مراكز درمانى، اطلاعات بالينى كه در يرونده كامل نبود، تكميل مى گرديد و بيمارانى كه روند درمان خاتمه يافته يا فوت نموده بودند از طريق تماس تلفنى وضعيت آنها بررسى مىشدند. بيماران مبتلا به سرطان پِتان از نظر زمان بقاى ه ساله (از زمان تشخيص تا ه سال) ييگيرى شدند.
است، و از طرفى اگر اين بيماران به ديابت نيز مبتلا باشند، عوارض مربوط به بيمارى ديابت، مشكلاتى را در روند درمان آنها ايجاد نموده كه احتمال مىرود كه زمان بقاى بيماران را تحت تاثير قرار دهد. لذا كنترل عوامل خطر بالاخص ابتلا به ديابت و كنترل دقيق هايير گليسمى در اين بيماران اهميت بهسزايى در افزايش ميزان بقاى آنها خواهد داشت. اين مطالعه با هدف بررسى رابطه ديابت و عوامل خطر با بقاى بيماران با ابتلا به سرطان ֶستان در مراكز درمان سرطان تحت گيوشش دانشعاه علوم يزشكى مشهد انجام گرديد.

\section{مواد و روشها}

اين مطالعه به صورت توصيفى - تحليلى انجام گرديد. از آنجايى كه پييگيرى زمان بقاى ه ساله بيماران در اين مطالعه مد نظر بود، جامعه آمارى اين يزوهش؛ از بين

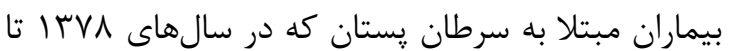

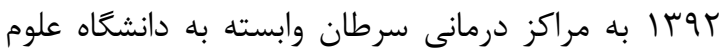

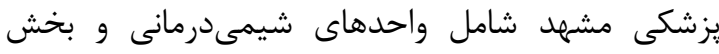

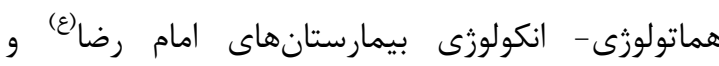
قائم (ع) مراجعه كرده بودند، انتخاب شدند. معيارهاى ورود شامل بيماران زن با تشخيص ياتولوزى كارسينوم يستان در سرطان يستان بود. معيارهاى خروج شامل: وجود سابقه فاميلى سرطان يستان (بستخان درجه يك و دو)، عدم انجام كامل درمان سرطان كه توسط يزشك معالج تجويز شده توسط بيمار به علت ترك بيمارستان با رضايت شخصى يا عدم مراجعه براى تكميل درمان بود. نمونه (random sampling Systematic) روش مستلزم انتخاب هر واحد K امين ليست، با استفاده از نقطه شروعى است كه بهطور تصادفى انتخاب شده بود. براى استفاده از اين روش نمونهگيرى بايد تعداد عناصر جمعيت و حجم نمونه مورد انتظار مشخص گردد. بدين صورت كه يس از اخذ تاييديه كميته اخلاق، يزوهشگر به مراكز نمونه گيرى مراجعه نمود و فراوانى سرطان يستان 


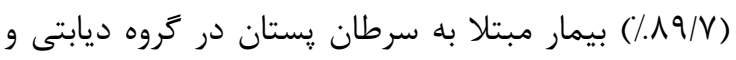

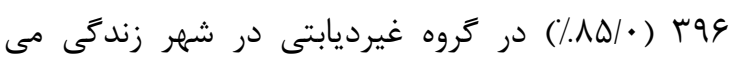

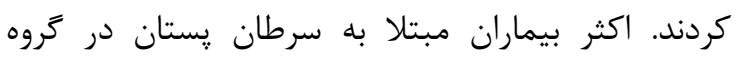

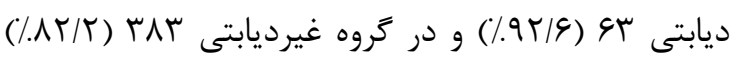

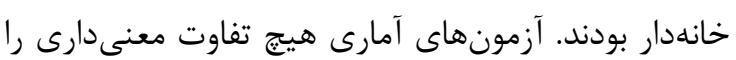

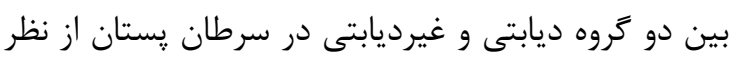
متغيرهاى فوق (تاهل، محل سكونت و شغل) نشان نداد. در بررسى عوامل خطر مرتبط با سرطان در بين دو گروه

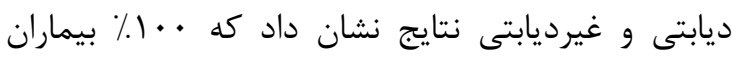
ديابتى و (49/4/) غيرديابتى استعمال سيعار نداشتند.

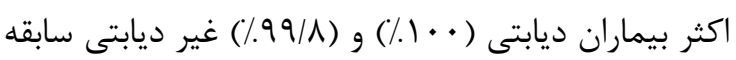
درمان جايگزين كننده هورمون در كذشته نداشتهاند

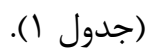

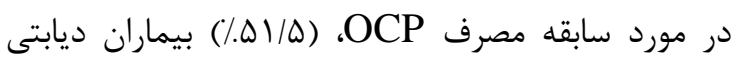

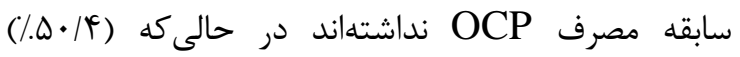
بيماران غيرديابتى مصرف OCP داشتهاند. نتايج ساير عوامل خطر همجون گيرنده استروزن، شاخص توده بدنى عيدر

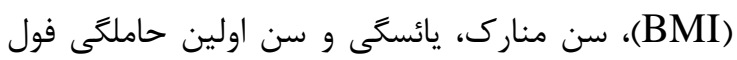
ترم در جدول r نشان داده شده است.

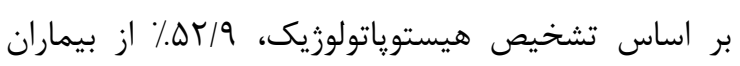

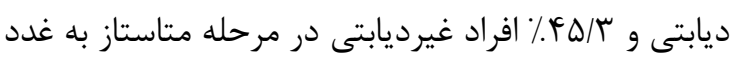

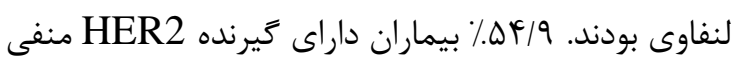

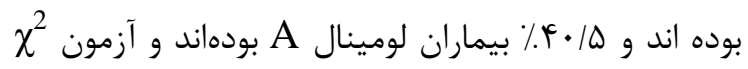

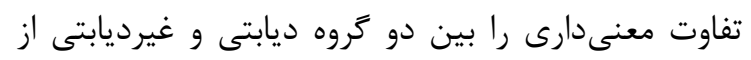
نظر گيرنده HER2 نشان نداد. ميانگين مقدار تومور
تشخيص سرطان پستان با توجه به معيارهاى طبقهبندى

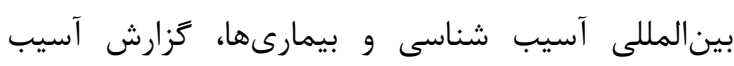
شناسى و معيارهاى سرطان كميسيون آمريكا انجام شد.

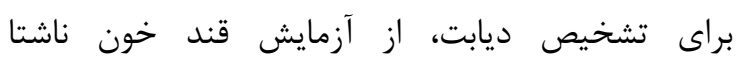
\126 mg/dL) كليكوزيله استفاده شد. در اين تحقيق بيمارانى كه در ابتداى بسترى تشخيص ديابت برايشان تاييد شده بود را

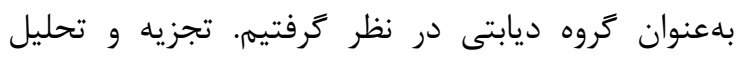

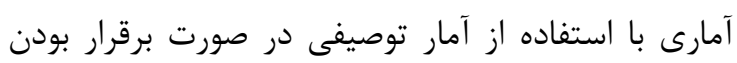

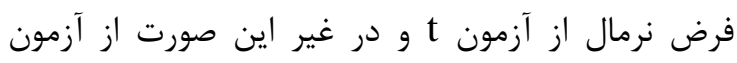

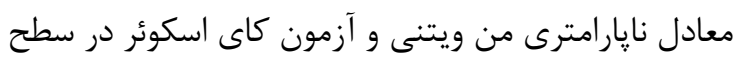

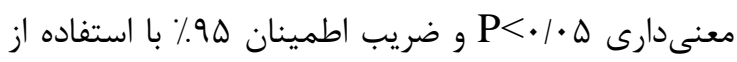
نرمافزار Spss نسخه IV مورد تجزيه و تحليل كرفت. از

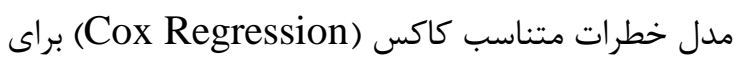
بررسى عوامل خطر و برآورد نسبت خطر (HR) و فواصل

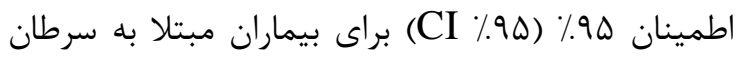
يستان با و بدون ديابت استفاده شده است.

\section{يافتهها} بر اساس نتايج مطالعه ع QM بيمار مبتلا به سرطان يستان

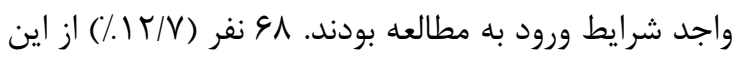

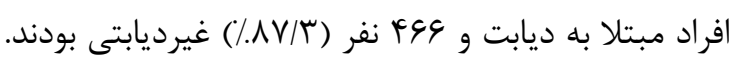
ميانكين سنى بيماران مبتلا به سرطان يستان و ديابتى SG/VD

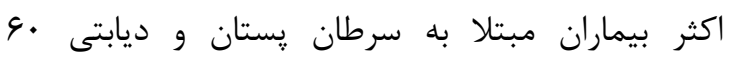

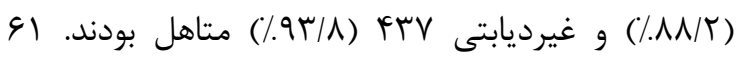

جدول ا: توزيع فراوانى عوامل خطر بيماران با سرطان بستان

\begin{tabular}{|c|c|c|c|c|}
\hline P- Value & درصد & تعداد & بيماران & متغير \\
\hline \multirow{2}{*}{$1 / \cdot$} & $1 \cdots$ & $9 \Lambda$ & ديابتيك & \multirow{2}{*}{ مصرف سيكار } \\
\hline & $99 / 4$ & FET & غيرديابتيك & \\
\hline \multirow{2}{*}{$1 / \cdot$} & $1 \cdots$ & $8 \Lambda$ & ديابتيك & \multirow{2}{*}{ 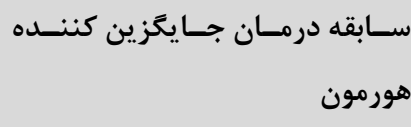 } \\
\hline & $99 / 1$ & $F \notin \Delta$ & غيرديابتيك & \\
\hline \multirow{2}{*}{$\cdot 1 \Lambda$} & $\Delta / / \Delta$ & $r \Delta$ & ديابتيك & \multirow{2}{*}{ OCP OCP ماشتن سابقه مصرف } \\
\hline & $4 q / 9$ & TM & غيرديابتيك & \\
\hline
\end{tabular}




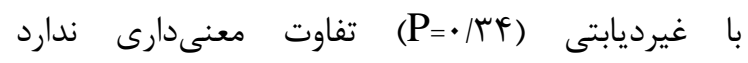

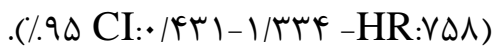
در ميان عوامل خطر فوق، خطر مرگ در بيماران مبتلا به سرطان يستان كه گيرنده استروزن مثبت دارند نسبت به بيمارانى كه گيرنده استروزن منفى دارند بر مبناى رگرسيون كاكس جند متغيره به طور معنى ييدا كرد، (CI95\%:0/109-0/907, 0/314: (CIR:) و (P=0/03). ساير عوامل خطر تفاوتى تاثيرى بر زمان بقا

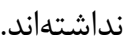

براى ورود متغيرها به مدل از روش backward LR

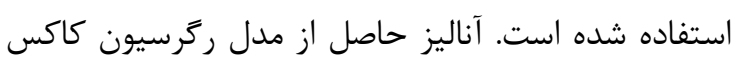

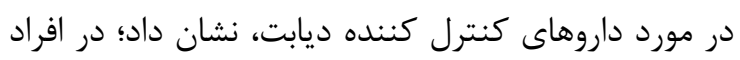

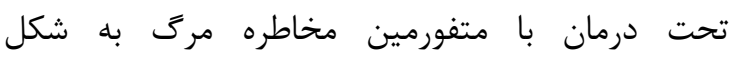
معنى ارىى كم شده و زمان بقا افزايش يافته است g (CI95\%: 0/226 - 0/950, HR: 0/5)

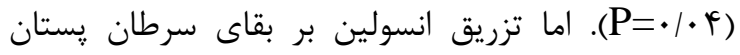

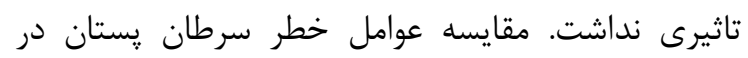

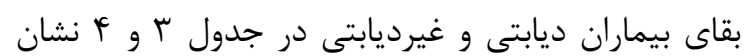

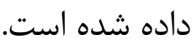

ماركر CA15-3، در بيماران ديابتى rV/VF (T\&/9)، و

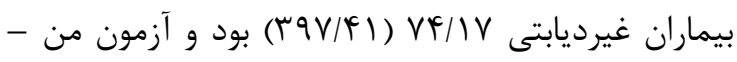
ويتنى در دو گروه ديابتى و غيرديابتى با سع|• P=فاوت معنى دارى را نشان نداد. برآوردى از ميزان بروز ديابت در بيماران با سرطان پِّتان

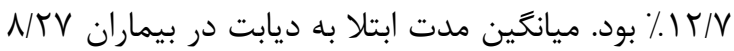
سال بود. در مورد تاريخجه درمان با داروهاى ضد (Y/NI) ديابتى، ( (FV/I/I) بيماران از متفورمين و كلى بنغلاميد و

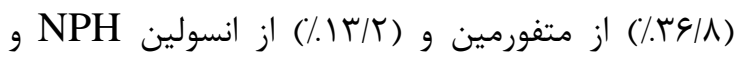
ركولار استفاده كرده بودند.

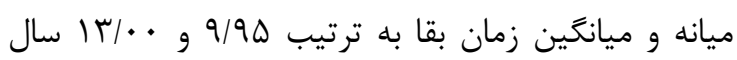
بود. براى بررسى تاثير ديابت بر زمان بقاى بيماران مبتلا به سرطان يستان در حضور تمام متغيرهاى تاثيرگذار (سن، محل اقامت، سابقه مصرف OCP، سن منارك، سن منويوز، سن اولين حاملگى فول ترم، BMI، گيرنده استروزن، يروزسترون، HER2، وضعيت زيرگروه از نظر حيرنده Luminal A ،HER2، Luminal B ، در مدل برازش شده و نتايج نشان داد، زمان بقاى بيماران ديابتى

جدول r: توزيع فراوانى عوامل خطر بيماران با سرطان يستان

\begin{tabular}{|c|c|c|c|c|}
\hline P- Value & انحراف معيار & ميانغين & بيماران & متغير \\
\hline \multirow{4}{*}{$\cdot \mid \Lambda \Lambda$} & $99 / 0$ & (f) & ديابتيك & \multirow{4}{*}{ كيرنده استروزن مثبت } \\
\hline & $V \cdot / V$ & rA. & غيرديابتيك & \\
\hline & $r \cdot / \Delta$ & 11 & ديابتيك & \\
\hline & $r q / r$ & 119 & غيرديابتيك & \\
\hline \multirow{2}{*}{$\cdot / \cdot v$} & $\Delta / r \Delta$ & $r q / 9$. & ديابتيك & \multirow{2}{*}{ BMI } \\
\hline & $\Delta / Q$. & TV/AD & غيرديابتيك & \\
\hline \multirow{2}{*}{$\cdot 111$} & 1/r & $\mid r / I V$ & ديابتيك & \multirow{2}{*}{ سن منارك } \\
\hline & $1 / 11$ & $1 T / 94$ & غيرديابتيك & \\
\hline \multirow{2}{*}{$.1 \cdot r$} & $r|9|$ & $p q / q \wedge$ & ديابتيك & \multirow{2}{*}{ سن يائسكى } \\
\hline & r/GT & $r q / . r$ & غيرديابتيك & \\
\hline \multirow{2}{*}{$\cdot 1 \cdot 1$} & $r / q q$ & $11 / 91$ & ديابتيك & \multirow{2}{*}{ سن اولين حاملكى فول ترم } \\
\hline & $r / F V$ & $19 / 94$ & غيرديابتيك & \\
\hline
\end{tabular}


جدول ץ: تاثير ديابت و متغيرهاى تاثير كذار در بقاى بيماران مبتلا به سرطان يستان بر مبناى ركرسيون كاكس تك متغيره

\begin{tabular}{|c|c|c|c|}
\hline P- Value & $95 \%$ CI & $\begin{array}{c}\text { HR } \\
\text { (Hazard Ratios) }\end{array}$ & Variable \\
\hline$\cdot / V V$ & $1 / 4 q 4-\cdot / V \cdot q$ &.$/ 9 \Delta 8$ & ديابت \\
\hline$\cdot|\cdot|>$ & $\cdot /$ / $q \vee \cdot / V \Delta q$ & $\cdot \mid \Delta F A$ & حيرنده استرورثن \\
\hline . IGTT & $\cdot \mid k V F-1 / \Delta V r$ & 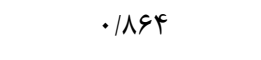 & متفورمين \\
\hline . ITrE & $\cdot / V G 4-r / \cdot q F$ & $1 / \Delta r q$ & انسولين \\
\hline
\end{tabular}

جدول F: تاثير ديابت و متغيرهاى تاثيركذار در بقاى بيماران مبتلا به سرطان يستان بر مبناى ركرسيون كاكس جندمتغيره

\begin{tabular}{|c|c|c|c|}
\hline P- Value & $95 \%$ CI & $\begin{array}{c}\text { HR } \\
\text { (Hazard Ratios) }\end{array}$ & Variable \\
\hline$\cdot / \mu F$ & • & $\cdot / V \Delta \Lambda$ & ديابت \\
\hline$\cdot / \cdot r$ & $\cdot / 1 \cdot 9-\cdot / 9 \cdot v$ & $\cdot / M I F$ & كيرنده استروثن \\
\hline$\cdot / \cdot f$ & $\cdot / \pi 94-\cdot / 90$ & $\cdot 10$ & متفورمين \\
\hline$\cdot / \Lambda$ & $. / / V T-q / 9 V V$ & $|/ \pi|$ & انسولين \\
\hline
\end{tabular}

معنادارى وجود ندارد (Yr). نتايج مطالعه بهروزى و همكاران (YIV) نشان داد كه در بيماران مبتلا به سرطان يستان، بين گروه ديابتى و غيرديابتى تفاوت معنى دارى از نظر زمان بقا وجود نداشت. بلهطورى كه ديابت به طور مستقل بر زمان بقا تاثيرى نداشته است (1)(1)، در حالى كه در مطالعه دى بروجن و همكاران (T/ • (Y) نتايج نشان داد، ديابت يك عامل خطر براى سرطان زّتان و همجنين مرگ ناشى از سرطان است

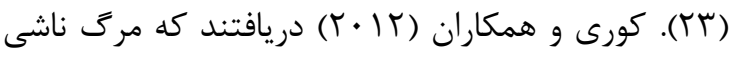
از سرطان، بهخصوص در سرطان يستان، در مبتلايان به ديابت، در مقايسه با افراد بدون ديابت افزايش يافته است

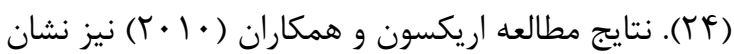
داد كه هيير گليسمى مزمن به طور معنى دارى با كاهش بقاى كلى در بازماندگان سرطان يستان اوليه همراه بوده است (YQ)، كه دليل تناقض اين نتايج با مطالعه حاضر بدين علت است كه مصرف متفورمين در بيماران ديابتى مبتلا به سرطان رِتان يك عامل افزايشدهنده زمان بقا بوده، كه البته نياز به تحقيقات بيشترى در اين زمينه است. نتايج مطالعه حاضر نشان داد كه BMI بيماران ديابتى مبتلا به سرطان : يستان بالاتر از بيماران غيرديابتى است.
بحث بر اساس آمار سازمان بهداشت جهانى، سرطان پِتان شايعترين سرطان در ميان زنان جهان و همجنين عامل مرگ ناشى از سرطان در ميان زنان در ايران است (9 (). شواهد اخير نشان داده كه بيش از نيم ميليون زن در ايران، جان خود بهعلت سرطان يستان از دست مىدهند و ميزان آن در ايران در حال افزايش است (• (†)، لذا مديريت سلامت در اين بيماران اهميت بهسزايى در افزايش ميزان بقاى آنها خواهد داشت. نتايج مطالعه حاضر نشان داد كه زمان بقاى بيماران مبتلا به سرطان يستان در افراد ديابتى با افراد غيرديابتى تفاوت

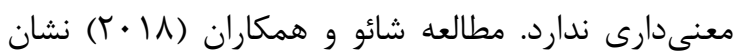
داد كه در بيماران مبتلا به سرطان يستان مبتلا به ديابت نوع r قبل از تشخيص، ميزان مرگ و مير در مقايسه با افراد بدون ديابت افزايش مىيابد (نسبت خطر /IV). مرگ و مير بيشتر هنگامى است كه ديابت نوع r در هنگام تشخيص يا بعد از تشخيص سرطان پستان تشخيص داده

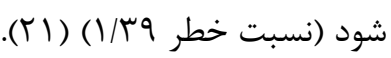
نتايج مطالعه ويلارئال-كارزا و همكاران (T/ • (ץ) نشان داد كه بين بيماران ديابتى و غيرديابتى از نظر زمان بقا تفاوت 


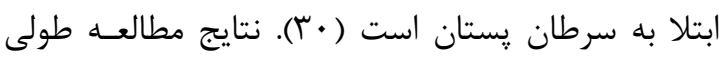

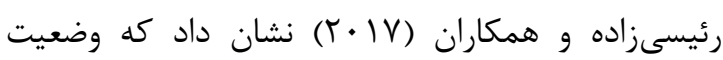

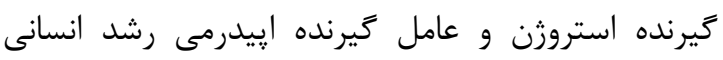
(HER2) تاثير معنىدارى را نشان داد (YY). نتايج مطالعه ساموئل و همكاران (1) (Y) نشان داد مقاومت به انسولين و كاهش توليد استروزن منجر به يك اختلال متابوليك پِيجيده مىشود كه به ايجاد سرطان در اندامهايى با نياز استرورن بالا از جمله يستان، آندومتر و تخمدانها كمك مى كند (آ). مقاومت به انسولين منجر به مكانيسم جبرانى مىشود كه باعث افزايش توليد آندروزن ها و كاهش توليد به ماليد

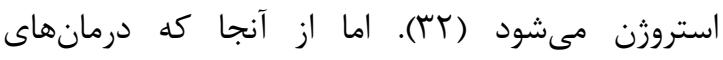
ضداسترورن (مثل تاموكسيفن و لتروزول) در افراد با دمان استروزن مثبت قابل انجام است، بنابراين با توجه به نتايج فوق مىتوان جنين نتيجه گيرى نمود كه كاهش خطر مرك در افراد ديابتى كه داراى استروثن مثبت بودهاند،

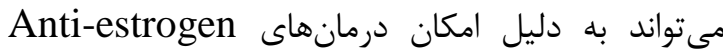
باشد. نتايج مطالعه حاضر بدنبال بررسى سابقه درمان با

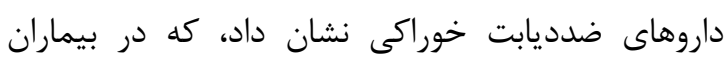

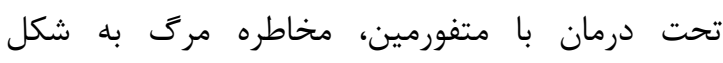
معنى دارى كم شده و زمان بقا افزايش يافته است. نتايج

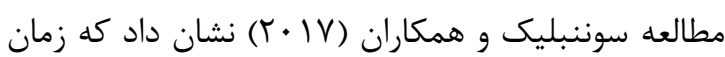
بقاى بيماران مبتلا به ديابت كه با متفورمين درمان نشده بودند، كمتر بوده است، متفورمين در بيماران مبتلا به ديابت كه HER2 مثبت و سرطان يستان با كيرنده هورمون مثبت داشتند، تأثيرى مثبت داشت (بّا). نتايج

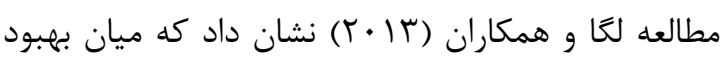

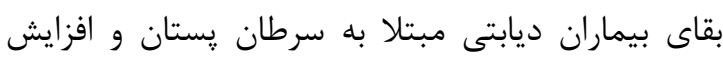

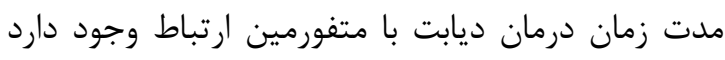

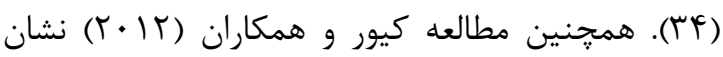
داد كه زمان بقا در بيمارانى كه تحت درمان با متفورمين بودند كاهش يافتهاند (هَ). مطالعه يُندى و همكاران نشان داد كه متفورمين خطر ابتلا به سرطان را كاهش

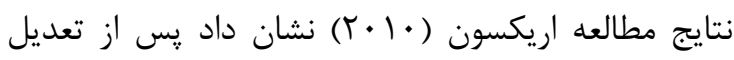

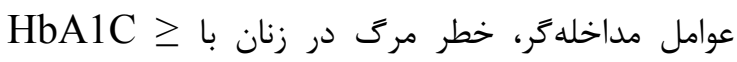

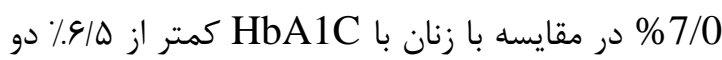
برابر گرديد (Tه)، جاقى ممكن است با نتايج بدتر سرطان

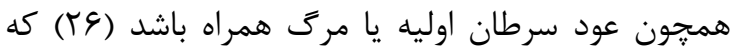
ممكن است بهعلت كاهش حساسيت به رزيمهاى درمانى ضدآنزيوزنيك باشد. اما به نظر مىرسد سندرم متابوليك و مقاومت به انسولين نيز از اهميت زيادى برخوردار است كه به نهان

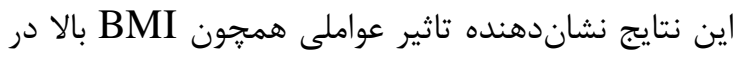

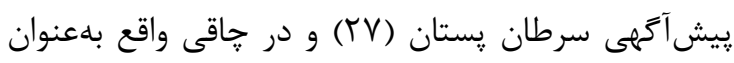
يك عامل خطر در بقاى بيماران ديابتى مبتلا به سرطان

$$
\text { يستان محسوب مى گَردد. }
$$

نتايج مطالعه حاضر نشان داد كه سن يائسكى بيماران ديابتى مبتلا به سرطان بستان بالاتر از بيماران غيرديابتى لهن

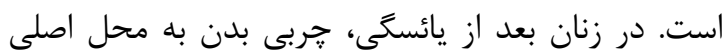
سنتز استرورن تبديل شده و بافت خربى بيشتر مىتواند ميزان استروزن را افزايش دهد. جاقى با كاهش توليد آدييونكتين، هورمون مشتق شده از خربى مرتبط است.

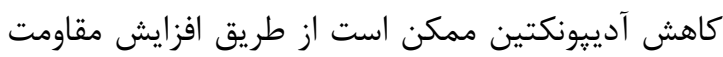

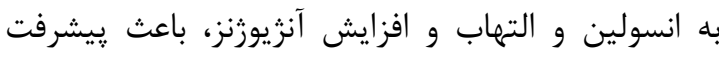

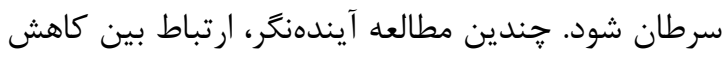

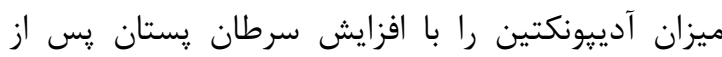

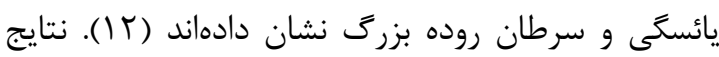
مطالعات نشان داده است كه عوامل هورمونى شامل: منارك زودرس، يائسگى ديررس، نولى خاريتى و سن بالا هنخام اولين باردارى فول ترم اثر زيادى در خطر بروز

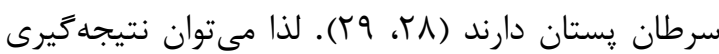

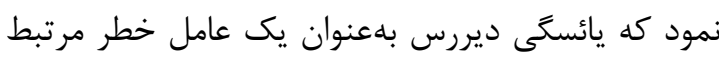
با سرطان يستان در زنان است. نتايج مطالعه حاضر نشان داد كه خطر مرى در در بيماران بان تشخيص سرطان يستان با گيرنده استروزن مثبت نسبت

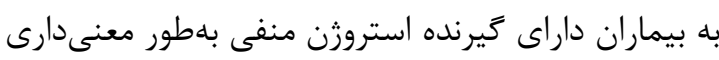
كاهش بيدا كرده است. قرار كرفتن در معرض استروزن و كيرنده استروزن مثبت يكى از عوامل تعيين كننده خطر 
همراه باشد (Y)). انسولين همجنين با افزايش سطح استروزن، باعث پيشرفت بيشتر سرطان يستان مىشود.

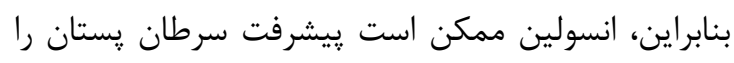
تسريع كرده و منجر به عود و مرى ناشى از سرطان

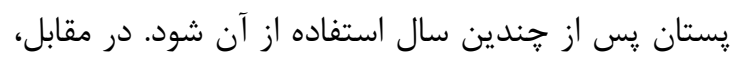

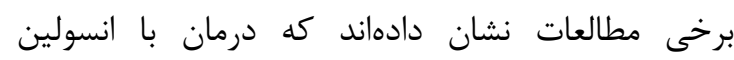
ييشبينى كننده يِيشآكمى ضعيفى براى بيماران مبتلا به سرطان يستان نيست (•) (א). عدم همخوانى اين نتايج با مطالعه حاضر احتمالا به دليل كنترل مناسب

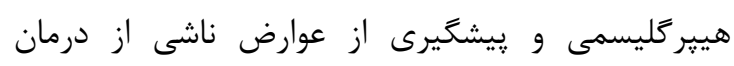

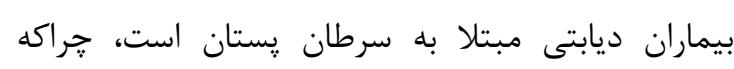
كنترل مناسب هيير كليسمى مزمن در بيماران ديابتى از

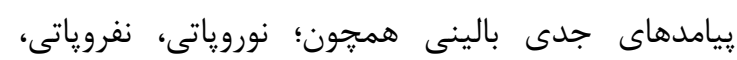
عوارض قلبى -عروقى، سكته مغزى و... جلوكيرى مىنمايد (با) كه كنترل اين عوارض بر افزايش زمان بقا بيماران مبتلا به سرطان بستان و داراى ديابت تاثير كذار خواهد

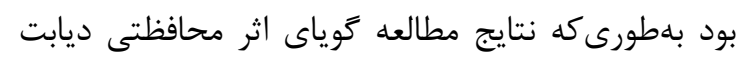
بر مرى ناشى از سرطان پِّتان بدون رابطه معنى دار

است.

بلهور كلى در بررسى مطالعات، رابطه بين ديابت و

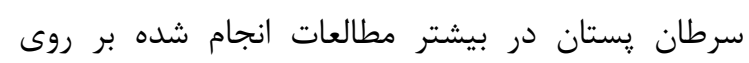

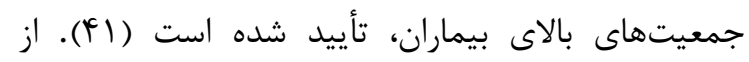
طرفى برخى از مطالعات افزايش خطر ابتلا به ديابت در بـاني

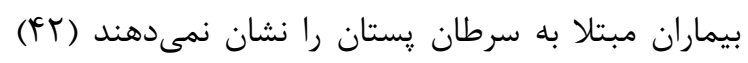

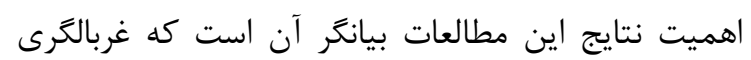

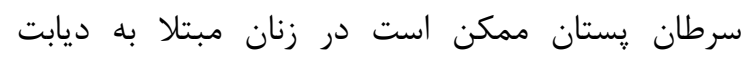

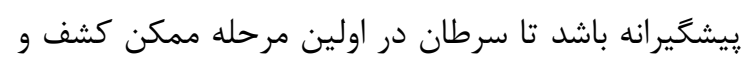

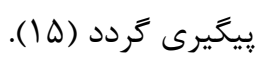

از محدوديتهاى اين يزوهش، كامل نبودن إن) اطلاعات

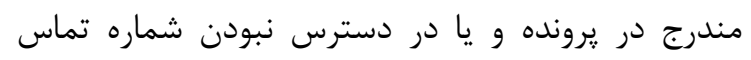

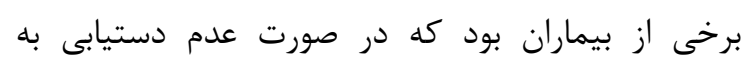

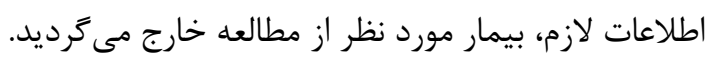

مىدهد (^). اما نتايج مطالعه باى ركتار (1) (1) نشان داد كه استفاده از متفورمين در طول شيمىدرمانى تاثير قابل توجهى در نتايج بقاى بيماران ديابتى مبتلا به

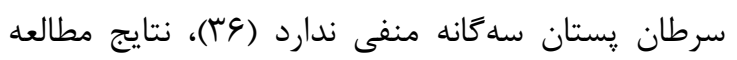

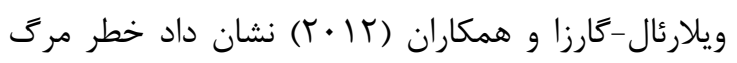

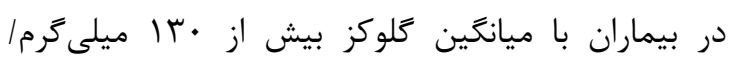
دسى ليتر در طى درمان، بيشتر بود (YT) (Y). مطالعه كولينز

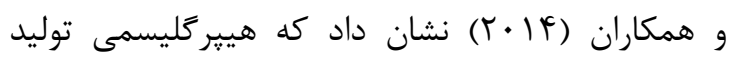
راديكالهاى آزاد را افزايش داده و موجب آسيب آسيب به هواد

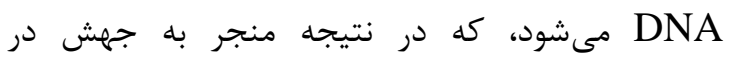
انكوزنها و زنهاى سركوب كننده تومور مىشود (T) (I ) و مىتواند باعث تكثير سلولهاى سرطانى شود. از نتايج

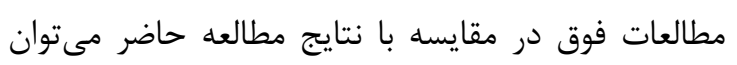
نتيجه متفورمين بر كنترل مناسب هييركّليسمى در بيماران ديابتى است. جراكه متفورمين يكى از داروهاى موثر بر مير كاهش قند خون بوده كه به طور گسترده بلهعنوان درمان

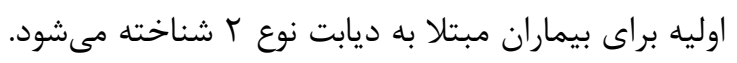

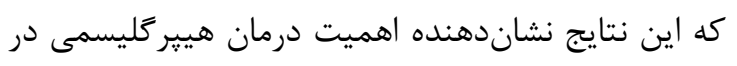

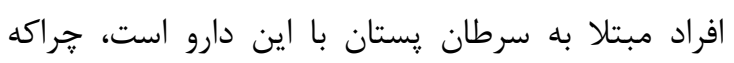
مى تواند تاثير مهمى بر زمان بقا در بيماران ديابتى مبتلا به سرطان يستان داشته باشد.

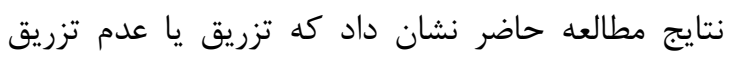

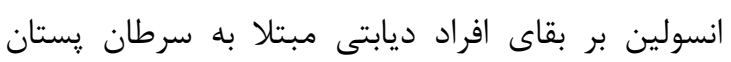
تاثيرى نداشته است. نتايج مطالعه سوننبليك و همكاران

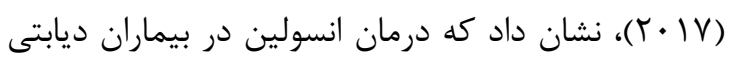

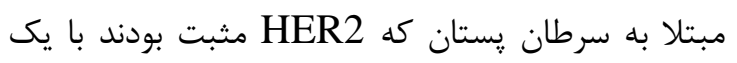
اثر مضر همراه است (بسا). نتايج مطالعه فرونى و همكاران

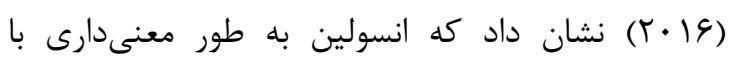

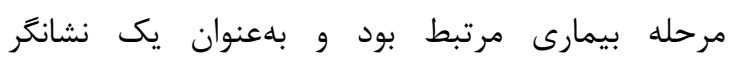

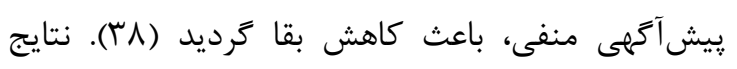

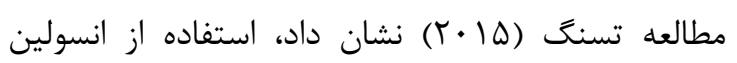

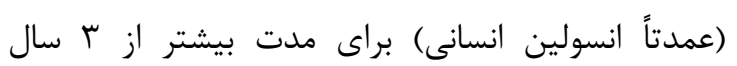

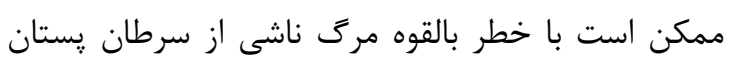




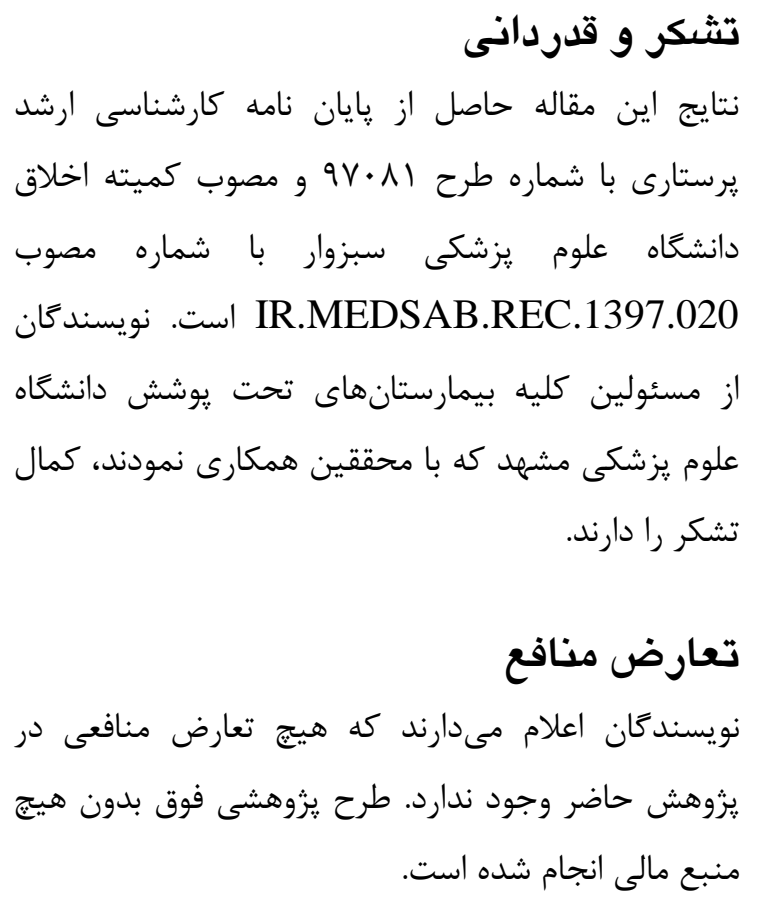

$$
\text { تونعارض منافع }
$$

\section{References}

1. DeSantis CE, Ma J, Gaudet MM, Newman LA, Miller KD, Goding Sauer A, et al. Breast cancer statistics, 2019. CA: a cancer journal for clinicians. 2019; 69(6):438-51.

2. Eketunde AO. Diabetes as a Risk Factor for Breast Cancer. Cureus. 2020;12(5): e8010.

3. Torre LA, Bray F, Siegel RL, Ferlay J, Lortet- Tieulent J, Jemal A. Global cancer statistics, 2012. CA: a cancer journal for clinicians. 2015; 65(2):87-108.

4. Akram M, Iqbal M, Daniyal M, Khan AU. Awareness and current knowledge of breast cancer. Biological research. 2017; 50(1):1-23.

5. EnayatRad M, Salehinia H. An investigation of changing patterns in breast cancer incidence trends among Iranian women. Journal of Sabzevar University of Medical Sciences. 2015; 22(1):27-35.

6. Zahedi A, Rafiemanesh H, Enayatrad M , Ghoncheh M, Salehiniya H. Incidence, trends and epidemiology of cancers in north west of Iran. Asian Pacific Journal of Cancer Prevention. 2015;16(16):7189-93.

7. Akbari ME, Sayad S, Sayad S, Khayamzadeh M, Shojaee L, Shormeji Z, et al. Breast Cancer

\section{نتيجهكيرى}

نتايج مطالعه حاضر بلهنبال يِيَيرى بقاى ه ساله بيماران با تشخيص سرطان يستان نشان داد كه هيبر گليسمى ناشى از ديابت مىتواند زمان بقاى بيماران مبتلا به سرطان پِتان را تحت تاثير قرار دهد بهطورى كه كنترل قند خون بهدنبال مصرف متفورمين باعث كاهش خطر مرى گرديد. در بين عوامل خطر نتايج مطالعه نشان داد كه در بيماران با گيرنده استروزن مثبت كاهش خطر مرى مشاهده گرديد، اما در رابطه با ساير عوامل خطر نياز به بررسى بيشتر است. اين نتايج اهميت ييشخيرى سطح اول و لزوم غربالكرى و ييخيرى مناسب در تشخيص زودرس سرطان پستان در خانمهاى در معرض خطر بالاى سرطان يستان و همراه با ابتلا به ديابت را مطرح مىنمايد.

Status in Iran: Statistical Analysis of 3010 Cases between 1998 and 2014. Int J Breast Cancer. 2017; 2017:2481021.

8. Jørgensen KJ, Kalager M, Barratt A, Baines C, Zahl P-H, Brodersen J, et al. Overview of guidelines on breast screening: Why recommendations differ and what to do about it. The Breast. 2017; 31:261-9.

9. Schrijvers D, Senn H-J, Mellstedt H, Zakotnik B. Cancer Prevention. Mashahad: Mashhad University of Medical Sciences; 2011.

10. Chamberlain JJ, Rhinehart AS, Shaefer Jr CF, Neuman A. Diagnosis and management of diabetes: synopsis of the 2016 American Diabetes Association Standards of Medical Care in Diabetes. Annals of internal medicine. 2016;164(8):542-52.

11. Wild S. Diabetes, treatments for diabetes and their effect on cancer incidence and mortality: attempts to disentangle the web of associations. Diabetologia. 2011; 54(7):158992.

12. Collins KK. The diabetes-cancer link. Diabetes Spectrum. 2014; 27(4):276-80.

13. Fedeli U, Zoppini G, Gennaro N, Saugo M. Diabetes and cancer mortality: a multifaceted 
association. Diabetes research and clinical practice. 2014;106(3):e86-e9.

14. Pandey A, Forte V, Abdallah M, Alickaj A, Mahmud S, Asad S, et al. Diabetes mellitus and the risk of cancer. Minerva endocrinologica. 2011; 36(3):187-209.

15. Bronsveld HK, Jensen V, Vahl P, De Bruin ML, Cornelissen S, Sanders J, et al. Diabetes and breast cancer subtypes. PloS one. 2017; 12(1):e0170084.

16. Dabrowski M, Szymanska-Garbacz E, Miszczyszyn Z, Derezinski T, Czupryniak L. Risk factors for cancer development in type 2 diabetes: A retrospective case-control study. BMC cancer. 2016; 16(1):785.

17. Onitilo AA, Engel JM, Glurich I, Stankowski RV, Williams GM, Doi SA. Diabetes and cancer I: risk, survival, and implications for screening. Cancer causes \& control. 2012;2 3(6):967-81.

18. Behrouzi B, Mohagheghi MA, Sadighi S. Demographic Characteristics, Survival and Prognostic Factors of Early Breast Cancer Patients with Type 2 Diabetes Mellitus: A Hospital-Based Cohort Study. Asian Pacific journal of cancer prevention: APJCP. 2017;18(9):2485.

19. WHO. Cancer country profiles http://www.who.int/cancer/countryprofiles/irn _en.pdf?ua=12014WHO; 2014 [cited 2017 October].

20. Farzaneh E, Heydari H, Shekarchi AA, Kamran A. Breast and cervical cancerscreening uptake among females in Ardabil, northwest Iran: a community-based study. OncoTargets and therapy. 2017; 10:985-92.

21. Shao S, Gill AA, Zahm SH, Jatoi I, Shriver CD, McGlynn KA, et al. Diabetes and overall survival among breast cancer patients in the US military health system. Cancer Epidemiology and Prevention Biomarkers. 2018; 27(1):50-7.

22. Villarreal-Garza C, Shaw-Dulin R, LaraMedina F, Bacon L, Rivera D, Urzua L, et al. Impact of diabetes and hyperglycemia on survival in advanced breast cancer patients. Experimental diabetes research. 2012; 2012.

23. De Bruijn K, Arends L, Hansen B, Leeflang S, Ruiter R, Van Eijck C. Systematic review and meta- analysis of the association between diabetes mellitus and incidence and mortality in breast and colorectal cancer. British Journal of Surgery. 2013; 100(11):1421-9.

24. Currie CJ, Poole CD, Jenkins-Jones S, Gale EA, Johnson JA, Morgan CL. Mortality after incident cancer in people with and without type 2 diabetes: impact of metformin on survival. Diabetes care. 2012; 35(2):299-304.
25. Erickson K, Patterson RE, Flatt SW, Natarajan L, Parker BA, Heath DD, et al. Clinically defined type 2 diabetes mellitus and prognosis in early-stage breast cancer. Journal of clinical oncology : official journal of the American Society of Clinical Oncology. 2011; 29(1):5460.

26. Pejhan A, Moghaddam HY, Najjar L, Akaberi A. The relationship between menarche age and anthropometric indices of girls in Sabzevar, Iran. J Pak Med Assoc. 2013; 63(1):81-4.

27. Bardou M, Barkun AN, Martel M. Obesity and colorectal cancer. Gut. 2013; 62(6):93347.

28. Kasper DL, Hauser SL, Fauci AS, Lango DL, Jameson JL, Loscalzo J, et al. Harrisons internal medicine. 19th, editor. United States of America: MCGraw-Hill; 2015.

29. L.hinkle J, H.Cheever K. Brunner\&Suddarths Textbook of Medical- Serjical Nursing. Reproduction and breast diseases 14th ed. Iran-tehran: Jame-e-Negar; 2018.

30. Yager JD, Davidson NE. Estrogen carcinogenesis in breast cancer. New England Journal of Medicine. 2006; 354(3):270-82.

31. Samuel SM, Varghese E, Varghese S, Büsselberg D. Challenges and perspectives in the treatment of diabetes associated breast cancer. Cancer treatment reviews. 2018; 70:98-111.

32. Suba Z. Interplay between insulin resistance and estrogen deficiency as co-activators in carcinogenesis. Pathology \& Oncology Research. 2012;18(2):123-33.

33. Sonnenblick A, Agbor-Tarh D, Bradbury I, Di Cosimo S, Azim HA, Jr., Fumagalli D, et al. Impact of Diabetes, Insulin, and Metformin Use on the Outcome of Patients With Human Epidermal Growth Factor Receptor 2-Positive Primary Breast Cancer: Analysis From the ALTTO Phase III Randomized Trial. Journal of clinical oncology : official journal of the American Society of Clinical Oncology. 2017; 35(13):1421-9.

34. Lega IC, Austin PC, Gruneir A ,Goodwin PJ, Rochon PA, Lipscombe LL. Association between metformin therapy and mortality after breast cancer: a population- based study. Diabetes care. 2013; 36(10):3018-26.

35. Currie CJ, Poole CD, Jenkins-Jones S, Gale EA, Johnson JA, Morgan CL. Mortality after incident cancer in people with and without type 2 diabetes: impact of metformin on survival. Diabetes care. 2012; 35(2):299-304.

36. Bayraktar S, Hernadez- Aya LF, Lei X, Meric- Bernstam F, Litton JK, Hsu L, et al. Effect of metformin on survival outcomes in 
diabetic patients with triple receptor- negative breast cancer. Cancer Causes Control. 2012; 118(5): 1202-11.

37. Reiszadeh M, Stegholeslami M, Zadeh MH, Malahi AS. Survival Analysis of Patients with Breast Cancer Considering Middle and Final Events :Application of Disease-Death Model. Iranian Journal of Epidemiology. 2017;13(m..252\#4):291-8.

38. Ferroni P, Riondino S, Laudisi A, Portarena I, Formica V, Alessandroni J, et al. Pretreatment insulin levels as a prognostic factor for breast cancer progression. The oncologist. 2016; 21(9): 1041-9.

39. Tseng $\mathrm{C}-\mathrm{H}$. Use of insulin and mortality from breast cancer among Taiwanese women with diabetes. Journal of diabetes research. 2015: 2015.

40. Mu L, Zhu N, Zhang J, Xing F, Li D, Wang $\mathrm{X}$. Type 2 diabetes, insulin treatment and prognosis of breast cancer. Diabetes/metabolism research and reviews. 2017; 33(1):e2823.

41. Gallagher EJ, LeRoith D. Obesity and diabetes: the increased risk of cancer and cancer-related mortality. Physiological reviews. 2015; 95(3):727-48.

42. Gallagher EJ, LeRoith D. The proliferating role of insulin and insulin-like growth factors in cancer. Trends in Endocrinology \& Metabolism. 2010; 21(10):610-8 